\title{
Kredi Risk Analizlerinde Diskriminant Analizi, Lojistik Regresyon ve Yapay Sinir Ağlarının Karșilaștırılması
}

Mehmet $\mathrm{YAZICI}^{1}$

Makale Gönderim Tarihi: 11.02 .2018

Makale Kabul Tarihi: 29.03.2018

\section{öz}

Bu çalıșmanın amacı risk değerlendirmesinin zor olduğu KO$B \mathrm{~B}^{\prime}$ lerde mali bașarısızlığın tahmini ile ilgili olarak alternatif bir yöntem ortaya koymaktır. Bankalarımızın son yıllardaki odak noktasını olușturan ve KOBI'lerle ilgili bașarısızlık tahminlerinde mali veriler tek bașına yeterli değildir. Bu çalıșmada, diskriminant analizi, lojistik regresyon ve yapay sinir ağı yöntemleri bir uygulama yapılarak karșılaștırılmıștır. lyi ve kötü kredi ayrımının yapay sinir ağı metodu ile daha bașarılı șekilde yapıldığı gözlemlenmiștir.

Anahtar Kelimeler: Diskriminant Analizi; Lojistik Regresyon; Yapay Sinir Ağı; Mali Bașarısızlık.

JEL Sınıflandırması: G01, G17, G33

Comparison of Discriminant Analysis, Logistic Regression and Artificial Neural Networks in Credit Risk Analysis

\section{ABSTRACT}

The aim of this study is to provide an alternative method for estimating the financial failure of SMEs where the risk assessment is difficult. Financial data are insufficient to predict the failure of

Doç. Dr., Esenyurt Üniversitesi İșletme ve Yönetim Bilimleri Fakültesi, mehmetyazici@ esenyurt.edu.tr, Orcid ld: 0000-0003-2924-9865 
SMEs, which is the focal point of our banks in recent years. In this study, the results of an application in discriminant analysis, logistic regression and artificial neural network methods were compared. It is observed that the distinction between good and bad credit has been best achieved by artificial neural networks method.

Keywords: Discriminant Analysis; Logistic Regression; Artifial Neural Network; Financial Failure.

Jel Codes: G01, G17, G33.

\section{GíRiș}

Son yıllarda ekonomi ve bankacılık alanında yașamıș olduğumuz dalgalanmalar, riskini doğru yönetemeyen, kaynaklarını verimli kullanamayan ve buna karșılık tașıdığı riski karșılayacak yeterli düzeyde sermaye bulundurmayan bankaların, nasıl kolayca krize sürüklenebileceğinin bir ispatı niteliğindedir. Son yıllarda Basel süreci ile birlikte bankaların karșı karșıya kaldığı riskler nedeni ile yükümlülüklerini yerine getiremeyecek duruma düșmesini önlemek, standart uygulamalar geliștirmek amacıyla global ve yerel düzeyde düzenlemelere gidilmiștir. Bu düzenlemeler ile bankaların ve ekonomik sistemin sağlıklı ișlemesine yönelik olarak, karșılașacakları muhtemel risklerin izlenmesi ve kontrolünü sağlamak üzere olușturacakları iç denetim ve risk yönetim sistemlerine ilișkin esas ve usullerin belirlenmesi, tașınan risklere karșılık yeterli sermayenin bulundurulması amaçlamakładır. Riskin doğru yönetilmesi potansiyel risklerin önceden tahmin edilerek gerekli aksiyonların bugünden alınmasına bağlıdır. Mali bașarısızlığın tahmin edilmesiyle ilgili bugüne kadar pek çok çalıșma yapılmıșıır (Akłaș, R.ve diğerleri, 2003; Arslan, O., 2003; Aktaș, R., 1997; Yıldız, B., 1999; Aziz, A. ve diğerleri 1998; Aktaș, R., 1993). Bu çalıșmaların bir kısmı da yöntem karșılaștırmalarına yöneliktir (Paket, H., 2014; Burmaoğlu, S., 2009; Ocakoğlu, G., 2006; Sığırlı, D., 2006; Güneri, N., 2001; Altman, E. ve diğerleri, 1994, Altman, E. ve diğerleri, 1968). Ancak yapılmıș olan bu çalıșmada, ekonomimizin temel dayanak noktası olan KOBi'lerle ilgili bașarısızlık tahminlerinde mali verilerin tek bașına yeterli olmadığından hareketle, sonuç üzerinde etkili olduğu düșünülen nitel değișkenlerin 
etkin olarak kullanıldığı sistemler tartıșılmıș ve sosyal bilimler alanında son 10 yıldır bașarılı olarak kullanılmakta olan yapay sinir ağları (McNelis, P., 2005; Elmas, C.., 2003; Öztemel, E., 2003; Haykin, S., 1999; Bishop, C., 1997; Schalkof, R., 1997; Trippi, R. ve Efraim, T., 1996; Wilkson, R. L. ve Sharda, R., 1994; Cichocki, A. ve Unbehaven, R., 1993; Coast, K. ve Fant, F., 1993, Vemuri, V., 1992) lojistik regresyon ve diskriminant analizi (Gümüș, D., 2015; Kalaycı, Ș., 2005; Tatlıdil, H., 2002; Eisenbeis, R., 1977) yöntemleri karșılaștırılmıș ve risk ölçümünün büyük ölçekli kurumsal firmalara oranla daha zor olduğu KOBílerde mali bașarısızlığın tahmininde alternatif bir yöntem olarak yapay sinir ağlarının karar destek sistemi olarak öne çıktığı görülmüștür.

\section{Modelde Yer Alan Veri Setinin Özellikleri}

Veri seti olușturulurken KOBi'lere yönelik mali bașarısızlık tahmin sisteminin geliștirilmesi için bir ticari bankanın kayı sistemi üzerinden 40 mio TL'ne kadar yıllık net satıșı 250 kișiden az çalıșanı olan firmalar tesadüfi olarak seçilmiș, 42 adet bașarısız ve 58 adet bașarılı ișletme incelemeye alınmıștır. KOBi'ler için 4 Kasım 2012 tarihli resmi gazetede yayınlanan tanım kullanılmıștır. 2006-2016 yıllarını içine alan inceleme dönemine ait firma verileri incelenmiștir. Modelde diğer çalıșmalardan farklı olarak KOBi'lerde özellikle mali verilerin sağlıklı olmaması, kayıt dıșılı̆̆ın fazlalığı, profesyonel finans yönetiminin bulunmaması gibi nedenler ile finansal faktörler yanında (25 adet), subjektif faktörlere de yer verilmiștir ( 9 adet). Yine aynı dönemlerde belli makro ekonomik kriterlerin karar mekanizması ile ilișkisinin test edilmesine yönelik olarak kriterler eklenmiștir (20 adet). Toplamda 54 adet değișkenin karar sistemi ile ilișkisi test edilmiștir. Modelde kullanılan bașarısızlık tanımına göre kredi taksit veya anapara borçlarına 90 gün boyunca ödeme yapmamıș ișletmeler bașarısız, ödemelerini düzenli yapmıș olan ișletmeler bașarılı olarak nitelendirilmiștir.

\section{Modelde Kullanılan Bağımsız Değișkenler}

Modelde kullanılan 54 bağımsız değișken nicel ve nitel olmak üzere iki grupta incelenmektedir. 


\section{Tablo 1. Modelde Kullanılan Değișkenler}

\begin{tabular}{|c|c|c|}
\hline Değișken & Değișken Açıklaması & Birim \\
\hline $\mathrm{X} 1$ & Net İșletme Sermayesi & $\mathrm{TL}$ \\
\hline $\mathrm{X} 2$ & Cari Oran & $\%$ \\
\hline X3 & Likidite Oranı & $\%$ \\
\hline X4 & Nakit Oran & $\%$ \\
\hline X5 & Ticari Alacaklar/Satıșlar (\%) & $\%$ \\
\hline X6 & Ticari Alacak Devir Hızı (Adet) & Adet \\
\hline $\mathrm{X7}$ & Ticari Alacak Tahsil Süresi (Gün) & Gün \\
\hline$x 8$ & Stok Devir Hızı (Adet) & Adet \\
\hline x9 & Stok Devir Süresi (Gün) & Gün \\
\hline $\mathrm{X} 10$ & Kısa Vadeli Borçlar/Özkaynak (\%) & $\%$ \\
\hline $\mathrm{X} 11$ & Yabancı Kaynaklar/Özkaynak (\%) & $\%$ \\
\hline $\mathrm{X} 12$ & Yabancı Kaynaklar/Aktifler (\%) & $\%$ \\
\hline $\mathrm{X} 13$ & Özkaynak Devir Hızı (Adet) & Adet \\
\hline $\mathrm{X} 14$ & Maddi Duran Varlıklar/Özkaynak (\%) & $\%$ \\
\hline $\mathrm{X} 15$ & Olağan Kar/Özkaynak (\%) & $\%$ \\
\hline $\mathrm{X} 16$ & Olağan Kar/Aktifler (\%) & $\%$ \\
\hline $\mathrm{X} 17$ & Olağan Kar/Net Satıșlar (\%) & $\%$ \\
\hline $\mathrm{X} 18$ & Net Kar/Özkaynak (\%) & $\%$ \\
\hline $\mathrm{X} 19$ & Net Kar/Aktifler (\%) & $\%$ \\
\hline $\mathrm{X} 20$ & Firmanın Faaliyet Süresi & Yıl \\
\hline $\mathrm{X} 21$ & Ortakların Tecrübesi & Yıl \\
\hline $\mathrm{X} 22$ & Ortak Sayısı & Adet \\
\hline $\mathrm{X} 23$ & Çalıșılan Banka Sayısı & Adet \\
\hline $\mathrm{X} 24$ & Dönem Kar/Zarar & $\mathrm{TL}$ \\
\hline $\mathrm{X} 25$ & Net Satıșlar & $\mathrm{TL}$ \\
\hline $\mathrm{X} 26$ & Grup Șirketlerinin Varlığı & Var ise 1 , yok ise 0 yazılmıștır. \\
\hline $\mathrm{X} 27$ & Protestolu Çek/Senet Kaydı & $\begin{array}{l}\text { Protestolu Cek/Senet kaydı var ise } 0 \text {, yok } \\
\text { ise } 1 \text { yazılmıștır. (On yıl içinde olușan ka- } \\
\text { yıtlar dikkate alınmıștır.) }\end{array}$ \\
\hline $\mathrm{X} 28$ & İșyerinin Firmaya Ait Olup Olmadığı & $\begin{array}{l}\text { İșyeri firmaya ait ise } 1 \text {, değil ise } 0 \text { yazılmıș- } \\
\text { tır. (İșyerinin ortaklardan herhangi birine } \\
\text { ait olması durumunda da } 1 \text { yazılmıștır.) }\end{array}$ \\
\hline X29 & Faktoring Yapıp Yapmadığı & $\begin{array}{l}\text { Firma, belirli finans gruplarının dıșında } \\
\text { kalan bir firmada faktoring yapıyor ise } 0 \text {, } \\
\text { yapmıyor ise } 1 \text { yazılmıștır. }\end{array}$ \\
\hline $\mathrm{X} 30$ & Ana Ortağın Öğrenim Durumu & Lise ve üzeri ise 1 , değil ise 0 yazılmıștır. \\
\hline
\end{tabular}




\begin{tabular}{|c|c|c|}
\hline X31 & Devam Eden Yatırımın Varlığı & $\begin{array}{l}\text { Devam eden yatıım var ise } 0 \text {, yok ise } 1 \\
\text { yazılmıștır. }\end{array}$ \\
\hline X32 & Satıșların Mevsimselliği & $\begin{array}{l}\text { Satıșlar mevsimsel ise } 0 \text {, değil ise } 1 \text { yazıl- } \\
\text { mıștır. }\end{array}$ \\
\hline X33 & Profesyonel Finans Yönetiminin Varlığı & $\begin{array}{l}\text { Profesyonel finans yönetimi varsa } 1 \text {, yoksa } \\
0 \text { yazılmıștır. }\end{array}$ \\
\hline X34 & Firma ve/veya ortaklar adına icra kaydı & $\begin{array}{l}\text { İcra kaydı var ise } 0 \text { ile ișaretlenirken, icra } \\
\text { kaydı yok ise } 1 \text { ile ișaretlenmiștir. }\end{array}$ \\
\hline $\mathrm{X} 35$ & GSMH & USD \\
\hline $\mathrm{X} 36$ & GSMH (Kiși Bașına) & USD \\
\hline$x 37$ & Büyüme & $\%$ \\
\hline $\mathrm{X38}$ & Tüfe (Yıl Sonu) & $\%$ \\
\hline X39 & $\$(Y, \mid$ Ortalaması) & $\mathrm{TL}$ \\
\hline $\mathrm{X} 40$ & İșsizlik Oranı & $\%$ \\
\hline$X 41$ & Kamu Brüt İç Borç Stoku & $\mathrm{TL}$ \\
\hline$X 42$ & Kamu Brüt Dıș Borç Stoku & USD \\
\hline $\mathrm{X} 43$ & İhracat (FOB) & USD \\
\hline $\mathrm{X} 44$ & Ithalat (FOB) & USD \\
\hline X45 & Dıș Ticaret Dengesi & USD \\
\hline$X 46$ & Cari İșlemler Dengesi & USD \\
\hline $\mathrm{X} 47$ & Emisyon & $\mathrm{TL}$ \\
\hline$X 48$ & M1 & $\mathrm{TL}$ \\
\hline X49 & M2 & $\mathrm{TL}$ \\
\hline$\times 50$ & M2Y & $\mathrm{TL}$ \\
\hline X51 & TL Mevduat & $\mathrm{TL}$ \\
\hline $\mathrm{X} 52$ & YP Mevduat & $\mathrm{TL}$ \\
\hline$\times 53$ & Kredi Stoku & $\mathrm{TL}$ \\
\hline $\mathrm{X54}$ & MB UA Döviz Rezervleri & USD \\
\hline Y & Bağımlı Değișken & $\begin{array}{l}\text { Sorunlu firma ise } 0 \text {, değilse } 1 \text { yazılmıștır. } \\
\text { (Sorunlu kredi tanımına karșilıklar karar- } \\
\text { namesine göre } 90 \text { gün ödeme yapmamıș } \\
\text { firmalar alınmıștır. Bunlardan bazıları daha } \\
\text { sonra normal çalıșmalarına geri dönerken, } \\
\text { bazıları tasfiye sürecine girmiștir.) }\end{array}$ \\
\hline
\end{tabular}




\section{Diskriminant, Lojistik Regresyon ve Yapay Sinir Ağı Uygulaması}

\section{i. Araștırma ve Yöntem}

Bu çalıșmada 100 adet șirketin verileri kullanılmıștır. Bağımlı değișken, sorunlu firma ise 0 , sorunlu firma değil ise 1 șeklinde kodlanmıștır. Sorunlu kredi tanımına Karșilıklar Kararnamesine göre 90 gün ödeme yapmamıș firmalar alınmıștır. Bunlardan bazıları daha sonra normal çalıșmalarına geri dönerken, bazıları tasfiye sürecine girmiștir. Eldeki verilerden hareketle verilere hem lojistik regresyon hem de diskriminant analizi uygulanmıștır. Lojistik regresyonda, bağımsız değișkenlerin dağılım özelliklerine yönelik bir șart olmamasına rağmen, diskriminant analizinde bağımsız değișkenlerin çoklu normal dağılıma uyması beklenir. Ancak nominal bağımsız değișkenler de diskriminant analizinde kullanılabilir. Eğer bağımsız değișkenlerin çoğunluğu sürekli ise, her iki yöntemde kullanılabilir. Bu araștırmada sürekli değișkenlerin sayısı çoktur. Bu sebeple her iki yöntem de denenecektir. Calıșmada SPSS 24, Release 13.0 ve ThinksPro paket yazılımları kullanılmıștır.

\section{ii. Diskriminant ve Lojistik Regresyon Analizi}

Fisher lineer diskriminant fonksiyonu katsayıları, skorlara dayalı olarak performans ölçüsünün derecelendirilmesini sağlamaktadır. Bu katsayılar, bağımsız değișkenlerin grupların ayrılmasına ne kadar katkıda bulunduklarını (ne düzeyde iyi tahmin edici olduklarını) tanımlamaktadır. Sorunlu firma ve sorunsuz firma sütunlarında yer alan büyük katsayılar, büyük katkıyı gösterirken küçük katsayılar ise daha düșük katkıyı ifade etmektedir. Bu durumda gruplara ayırmada en fazla katkıda bulunan değișken protestolu çek/senet kaydıdır. Onu sırasıyla profesyonel finans yönetiminin varlığı, satıșların mevsimselliği, nakit oran izlemektedir. En düșük katkıyı sağlayan değișkenler nakit oran ve TL mevduat değișkenleridir. 
Tablo 2. Fisher'in Lineer Diskriminant Fonksiyonu

\begin{tabular}{lcc}
\hline & \multicolumn{2}{c}{ Sorunlu/sorunsuz firma } \\
\cline { 2 - 3 } & Sorunlu firma & Sorunsuz firma \\
\hline Nakit oran &, 085 &, 029 \\
Maddi duran varlıklar/özkaynak &, 043 &, 027 \\
Protestolu çek/senet kaydı & 10,197 & 6,922 \\
Satıșların mevsimselliği & 4,875 & 2,263 \\
Profesyonel finans yönetiminin varlığı & 8,526 & 4,607 \\
TL Mevduat &,- 042 &, 033 \\
(sabit) & $-12,716$ & $-7,707$ \\
\hline
\end{tabular}

Tablo 3. Standardize Edilmiș Diskriminant Fonksiyonu Katsayıları

\begin{tabular}{lc}
\hline & \multicolumn{2}{c}{ Fonksiyon } \\
\cline { 2 - 2 } & 1 \\
\hline Nakit oran & 0,751 \\
Maddi duran varlıklar/özkaynak & 0,504 \\
Protestolu çek/senet kaydı & 0,473 \\
Satıșların mevsimselliği & 0,509 \\
Profesyonel finans yönetiminin varlığı & 0,736 \\
TL Mevduat & $-1,033$ \\
\hline
\end{tabular}

Tabloda standardize olmayan diskriminant katsayıları verilmiștir. Diskriminant fonksiyonunu yazacak olursak;

$Z=0,751$ (X4=nakit oran) $+0,504$ (X14=maddi duran varlıklar/özkaynak $)+0,473(X 27=$ protestolu çek/senet kaydı) + 0,509 (X32=satıșların mevsimselliği) $+0,736$ (X33=profesyonel finans yönetiminin varlığı) - 1,033 (X51 =TL mevduat) 
Tablo 4. Diskriminant Analizi Deney Grubu Sinıflandırma Tablosu

\begin{tabular}{llccc}
\hline & & \multicolumn{2}{c}{ Tahmin edilen grup } & Toplam \\
\cline { 3 - 5 } & & Sorunlu firma & Sorunsuz firma & \\
\hline \multirow{2}{*}{ Adet } & Sorunlu firma & 17 & 4 & 21 \\
& Sorunsuz firma & 3 & 26 & 29 \\
\hline \multirow{2}{*}{$\%$} & Sorunlu firma & 80,95 & 19,05 & 100 \\
& Sorunsuz firma & 10,34 & 89,66 & 100 \\
\hline
\end{tabular}

Tabloda görüldüğü üzere firma sorunlu iken gerçekten sorunlu grubuna atanmıș 17 gözlem, firma sorunlu iken sorunsuz firma grubuna atanan 4 gözlem, firma sorunsuz iken sorunlu firma grubuna atanan 3 gözlem, firma sorunsuz iken sorunsuz gruba atanan 26 gözlem vardır. Doğru sınıflandırma yüzdesi Deney Grubunda ortalama \%85 olarak bulunmuștur.

\section{Tablo 5. Diskriminant Analizi Test Grubu Sinfflandırma Tablosu}

\begin{tabular}{clccc}
\hline & & \multicolumn{2}{c}{ Tahmin edilen grup } & Toplam \\
\cline { 3 - 5 } & & Sorunlu firma & Sorunsuz firma & \\
\hline \multirow{2}{*}{ Adet } & Sorunlu firma & 10 & 11 & 21 \\
& Sorunsuz firma & 23 & 6 & 29 \\
\hline \multirow{2}{*}{$\%$} & Sorunlu firma & 47.62 & 52.38 & 100 \\
& Sorunsuz firma & 79.31 & 20.69 & 100 \\
\hline
\end{tabular}

Tabloda görüldüğü üzere firma sorunlu iken gerçekten sorunlu grubuna atanmıș 10 gözlem, firma sorunlu iken sorunsuz firma grubuna atanan 11 gözlem, firma sorunsuz iken sorunlu firma grubuna atanan 23 gözlem, firma sorunsuz iken sorunsuz gruba atanan 6 gözlem vardır. Doğru sınıflandırma yüzdesi Test Grubunda ortalama \%34 olarak bulunmuștur. Deney grubu verilerinin doğru sınıflandırma yüzdesi 85 iken, test grubu verilerinin doğru sınıflandırma yüzdesinin 34 olarak hesaplanması modelin güvenilirliğini olumsuz yönde etkilemektedir. 
Tablo 6. Lojistik Regresyon Denklem Değișkenleri

\begin{tabular}{rrrrccr}
\hline & \multicolumn{1}{c}{ B } & \multicolumn{1}{c}{ S.E. } & Wald & df & Sig. & \multicolumn{1}{c}{ Exp(B) } \\
\hline Step 1(a) X34 & 21,203 & 7463,647 & 0,000 & 1 & 0,998 & 1615474864 \\
Step 2(b) X34 & 56,359 & 13415,385 & 0,000 & 1 & 0,997 & 299559517649568 \\
X36 &,- 009 & 2,726 & 0,000 & 1 & 0,997 &, 991 \\
\hline
\end{tabular}

Tablo 7. Lojistik Regresyon Sınıflandırma Tablosu

\begin{tabular}{llccc}
\hline & & \multicolumn{2}{c}{ Sorunlu/sorunsuz firma } & \\
& Gözlem & Sorunlu firma & Sorunsuz firma & \% Doğru ayırma \\
\hline Adım 1 & Sorunlu firma & 0 & 21 & 0 \\
& Sorunsuz firma & 0 & 29 & 100 \\
& & & Toplam \% & 58 \\
\hline Adım 2 & Sorunlu firma & 21 & 0 & 100 \\
& Sorunsuz firma & 0 & 29 & 100 \\
& Overall Percentage & & & 100 \\
\hline
\end{tabular}

Tabloda görüldüğü üzere birinci adımda 21 adet gözlem sorunlu firma olmasına rağmen sorunsuz firma statüsüne atanmıștır. Birinci adımda sınıflandırma yapılamamıștır. İkinci adımda 21 adet sorunlu firma ve 29 adet sorunsuz firmanın doğru atandığı ve \%100 bașarı oranı elde edildiği görülmektedir.

Aynı verilere uygulanan iki farklı istatistiksel analiz olarak hem diskriminant analizi, hem de lojistik regresyon analizi sonuc-ları karșılaștııılmıștır. Diskriminant analizinde, diskriminant analizinin gerçekleșmesi için ihtiyaç duyulan üç varsayımdan normal dağılım ve eșit kovaryans varsayımları sağlanmıș ancak gözlem değerlerinin arttıılamamasından dolayı çoklu doğrusal bağlantı olmaması varsayımı sağlanamamıștır. Anlamlı bir diskriminant fonksiyonu bulunmuș ve değișkenler varyansın \%60'ını açıklayabilmeyi bașarmıștır. 6 değișkenden olușan anlamlı bir model elde edilmiș ve sınıflandırma așamasında Deney Grubunda \%85, Test Grubunda \%34 bașarı sağlanmıștır. Lojistik regresyon analizinde, iki değișkenli bir lojistik regresyon modeli elde edilmiș ancak bu modelin verilerin ayrımını iyi temsil ettiği hipotezi reddedilmiștir. Model parametrelerinin anlamlı olduğu hipotezi kabul edilse de 
hepsinin sıfıra eșit olduğu hipotezi de kabul edilmiștir. Değișkenler verileri açıklamak için ayrı ayrı anlamlı olsa da genel olarak model anlamsızdır. \%100 bir sınıflandırma bașarısı sağlandığı yönünde bir sonuca ulașılamamıștır. Yapılan araștırma neticesinde üzerinde çalıșılan veriler ile ilgili analizlerde diskriminant analizinin daha sağlıklı ve doğru sonuç verdiği ortaya çıkmıștır.

Verileri ayrımsamada kullanılan \%86 oranında bașarılı olan diskriminant fonksiyonu:

$Z=0,751$ (X4=nakit oran) $+0,504$ (X14=maddi duran varlıklar/özkaynak $)+0,473(X 27=$ protestolu çek/senet kaydı) + 0,509 (X32=satıșların mevsimselliği) $+0,736$ (X33=profesyonel finans yönetiminin varlığı) - 1,033 (X51=TL mevduat)

Test grubu verilerini açıklamada yetersiz kalmakla birlikte diskriminant analizinin lojistik regresyona oranla daha sağlıklı bir ayırma yaptığı tespit edilmiștir.

\section{iii. Yapay Sinir Ağı Analizi}

Yapay Sinir Ağı Modelinde Kullanılan Parametreler:

Mimari Tipi

: Çok Katmanlı Normal Ileri Beslemeli

Hata Tipi

: Karesel Ortalama Hata

Eğitim Set Gözlem Adedi : : 50

Test Set Gözlem Adedi : 50

Değișken Adedi : :54

İterasyon Adedi $\quad: 108$

Katman Sayısı : : 3 
Tablo 8. YSA Parametre Tablosu

\begin{tabular}{llll}
\hline & Girdi & Gizli Katman & Çıkı \\
\cline { 2 - 4 } Düğümler & 54 & 1 & 1 \\
Maks. Düğümler & 54 & 15 & 1 \\
Öğrenme Kuralı & - & Hızlı Yayılma & Hızıł Yayılma \\
Girdi Fonksiyonu & Ortalama Standart Sapma & İç Çarpım & İç Çarpım \\
Transfer Fonksiyonu & - & Sigmoid & Sigmoid \\
\hline
\end{tabular}

Tablo 9. YSA Test Grubu Sınıflandırma Tablosu

\begin{tabular}{llccc} 
& & \multicolumn{2}{c}{ Tahmin edilen grup } & \\
Adet & Sorunlu firma & Sorunsuz firma & Toplam \\
& Sorunlu firma & 20 & 1 & 21 \\
& Sorunsuz firma & 1 & 28 & 29 \\
$\% \quad$ Sorunlu firma & 95,24 & 4,76 & 100 \\
& Sorunsuz firma & 3,44 & 96,56 & 100
\end{tabular}

Tabloda görüldüğü üzere firma sorunlu iken gerçekten sorunlu grubuna atanmıș 20 gözlem, firma sorunlu iken sorunsuz firma grubuna atanan 11 gözlem, firma sorunsuz iken sorunlu firma grubuna atanan 1 gözlem, firma sorunsuz iken sorunsuz gruba atanan 28 gözlem vardır. Doğru sınıflandırma yüzdesi Test Grubunda ortalama \%96 olarak bulunmuștur. Yapay sinir ağında öğrenme süreci 0 hata oranı ve \%100 doğru ayırma yapana kadar devam ettiğinden anlamlı bir mukayese için test grubu verileri ile karșılaștırma yapılması gerekmektedir. Bu kapsamda deney grubu verilerinin doğru sınıflandırma yüzdesi 100 iken, test grubu verilerinin doğru sınıflandırma yüzdesinin 96 olarak hesaplanması modelin güvenilir olduğunu ve KOBi'lerde alternatif yöntem olarak kullanılabileceğini göstermektedir. 


\section{Grafik 1. Yapay Sinir Ağı Sınıflandırma ve Hata Grafiği}

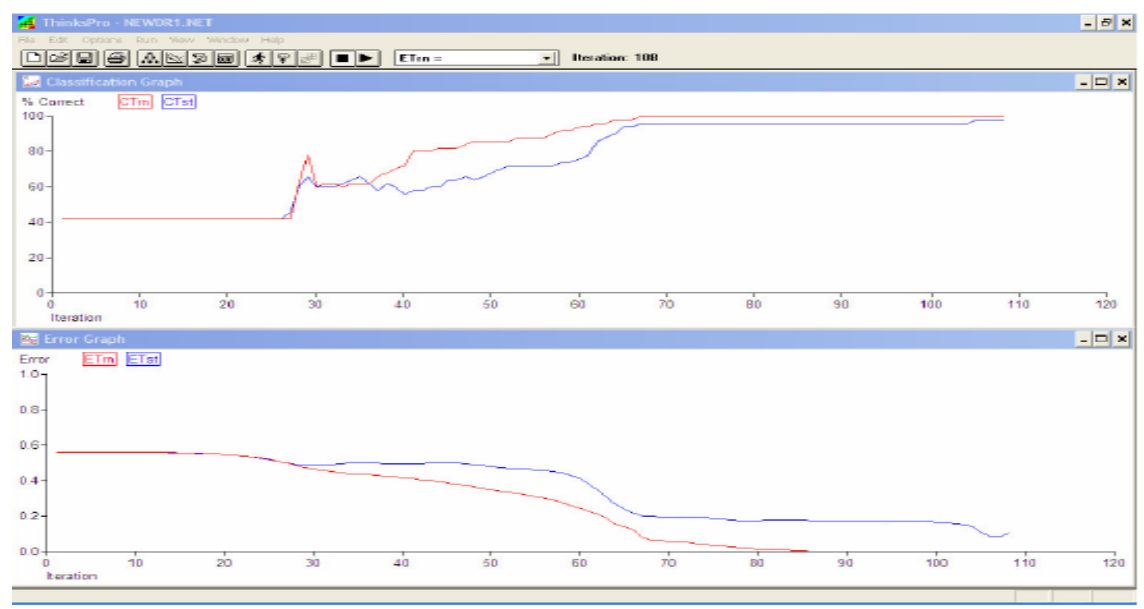

Yukarıdaki sınıflandırma ve hata grafiklerinde eğitim ve test setlerinin ayırma gücü ve hata oranları gösterilmekte olup kırmızı renkli çizgiler eğitim setinden elde edilen verileri, mavi renkli çizgiler test setinden elde edilen sonuçları göstermektedir.

\section{Sonuç}

Kaynakların en uygun vade ve faiz yapısı ile doğru müșteriye kullandırılması bankaların en önemli sorunlarından biridir. Doğru müșterinin tespiti, kredi değerliliğinin ölçülmesinde isabetli karar alınmasına yönelik karar destek sistemlerinin olușturulmasına bağlıdır. Bu konuda özellikle bankalar içsel derecelendirme sistemlerini geliștirmeye yönelik yoğun çalıșmalar yapmaktadırlar. Ancak günümüzde bankalar tarafından kullanılan ve ağırlıkla istatistik yöntemlere dayalı karar destek sistemleri özellikle profesyonel finans yönetimine sahip olmayan, mali verileri gerçeği yeterince yansıtmayan, firma ve sahibinin özdeșleștiği KOBi'lerde yeterli derecede açıklayıcı olamamakta, sübjektif faktörler yoğun olarak kullanılmakta ve kararlar pek çok bankada birbirinden farklı yapıda ve yoğun eleman istihdam edilen birimler içinde, standart dıșı, yüksek maliyetli, uzun karar süreçlerini içeren ortamlarda alınmaktadır. 
Bu çalıșma ile bankalarda en çok kullanılan karar destek sistemlerinden diskriminant analizi, lojistik regresyon ve yapay sinir ağı kullanılarak uygulamalar yapılmıș ve elde edilen sonuçlar karșılaștırılarak içlerinden en uygun yöntem olarak tespit edilen yapay sinir ağı yöntemi alternatif karar destek sistemi olarak önerilmiștir.

Diskriminant analizinde firma sorunlu iken gerçekten sorunlu grubuna atanmıș 10 gözlem, firma sorunlu iken sorunsuz firma grubuna atanan 11 gözlem, firma sorunsuz iken sorunlu firma grubuna atanan 23 gözlem, firma sorunsuz iken sorunsuz gruba atanan 6 gözlem tespit edilmiștir. Nakit oran, maddi duran varlıklar/özkaynak, protestolu çek/senet kaydı, satıșların mevsimselliği, profesyonel finans yönetiminin varlığı ve TL mevduat değișkenleri diskriminant fonksiyonu için anlamlı bulunmuștur. Deney grubu verilerinin doğru sınıflandırma yüzdesi 85 iken, test grubu verilerinin doğru sınıflandırma yüzdesinin 34 olarak hesaplanması modelin güvenilirliğini olumsuz yönde etkilemektedir.

Lojistik regresyon analizinde, iki değișkenli bir lojistik regresyon modeli elde edilmiș ancak bu modelin verilerin ayrımını iyi temsil ettiği hipotezi reddedilmiștir. Fonksiyon içinde firma ve/ veya ortaklar adına icra kaydı ile kiși bașı milli gelir değișkenleri anlamlı bulunmuștur. Değișkenler verileri açıklamak için ayrı ayrı anlamlı olsa da genel olarak anlamlı bir sonuç elde edilememiștir. Bu iki yöntemden elde edilen verilere bağlı olarak diskriminant analizinin lojistik regresyona göre daha sağlıklı bir sonuç ürettiği sonucuna varılmıștır.

Yapay sinir ağı uygulamasında ise firma sorunlu iken gerçekten sorunlu grubuna atanmıș 20 gözlem, firma sorunlu iken sorunsuz firma grubuna atanan 11 gözlem, firma sorunsuz iken sorunlu firma grubuna atanan 1 gözlem, firma sorunsuz iken sorunsuz gruba atanan 28 gözlem vardır. Doğru sınıflandırma yüzdesi Test Grubunda ortalama \%96 olarak bulunmuștur. Yapay sinir ağında öğrenme süreci 0 hata oranı ve \%100 doğru ayırma yapana kadar devam ettiğinden anlamlı bir mukayese için test grubu verileri ile karșılaștırma yapılmıș, bu kapsamda deney grubu verilerinin doğru sınıflandırma yüzdesi 100 iken, test grubu verilerinin doğru 
sınıflandırma yüzdesinin 96 olarak hesaplanmıștır. Modelin firmaları doğru gruba atama konusunda kayda değer bir sonuç üreterek KOBI kredilerinin değerlemesinde alternatif bir yöntem olarak kullanılabileceği kanaatine varıımıștır. Mali bașarısızlığın tahmin edilmesinde kullanılan hızlı ve isabetli karar alan modeller bilgisayar teknolojisindeki gelișmelere paralel olarak her geçen gün gelișmekte olup istatistiksel ve ileri tekniklerin bir arada kullanıldığı karma modeller bu sürecin geleceğini olușturacaktır. 


\section{KAYNAKÇA}

Aktaș R., Doğanay M., Yıldız B. (2003). Mali Bașarısızlığın Öngörülmesi: İstatistiksel Yöntemler ve Yapay Sinir Ağı Karșılaștırması, Ankara Üniversitesi S.B.F Dergisi, Ankara, Cilt:58, Sayı:4.

Aktaș R. (1993). Endüstri İșletmeleri İçin Mali Bașarısızlık Tahmini, T. İș Bankası Yayınları 323.

Aktaș R. (1997). Mali Bașarısızlık Tahmin Modelleri, İș Bankası Kültür Yayınları.

Altman E., Giancarlo M. and Franco V. (1994). Corporate Distress Diagnosis: Comparisons Using Linear Discriminant Analysis and Neural Networks (The Italian Experience), Journal of Banking and Finance 18.

Altman E. (1968). Financial Ratios, Discriminant Analysis and The Prediction of Corporate Bankruptcy, The Journal of Finance, V:XXIII, n:4, September.

Arslan Ö. (2003). Küçük ve Orta Ölçekli İșletmelerde CCalıșma Sermayesi ve Bazı Finansal Yönetim Uygulamaları, C.Ü. İktisadi Ídari Bilimler Fakültesi Dergisi, Cilt 4, Sayı 1.

Azız A., Emanuel D., Lawson G. (1988). Bankruptcy Prediction-An Investigation at Cash Flow Based Models, Journal of Management, V:25 n:5, September.

Bishop C. (1997). Neural Networks For Pattern Recognition, Clerendon Press, Oxford.

Burmaoğlu S. (2009). Birleșmiș Milletler Kalkınma Programı Beșeri Kalkınma Endeksi verilerini kullanarak diskriminant analizi, lojistik regresyon analizi ve yapay sinir ağlarının sınıflandırma bașarılarının değerlendirilmesi, Atatürk Üniv. SBE Yayınlanmamıș doktora tezi.

Cıchocki, A. and Unbehaven, R. (1993). Networks For Optimisation and Signal Processing, John Wiley and Sons, Stutgart.

Coast K., Fant F. (1993). Recognizing Financial Distress Patterns Using a Neural Network Toll, Financial Management, Autumn.

Eisenbers R. (1977). Piffalls in The Application of Discriminant Analysis in Business, Finance and Economics, The Jurnal of Finance, $\mathrm{V}: X X X I I N: 3$, June.

Elmas C.. (2003). Yapay Sinir Ağları, Seçkin Kitabevi, Ankara.

Gümüș D. (2015). Diskriminant analizi ve bireysel emeklilik üzerine bir uygulama, İstanbul Üniversitesi SBE, Yayınlanmamıș doktora tezi.

Güneri N. (2001). Öğrenci Bașarısızlıklarının Analizinde Sinir Ağları Yaklașımının

Lojistik Regresyon Analizi ile Karșılaștırılması, Yayınlanmamıș Yüksek Lisans Tezi, Ankara. 
Haykın S. (1999). Neural Networks: A Comprehensive Foundation, Prentice Hall International.

Kalaycı Ș. (2005). SPSS Uygulamalı Çok Değișkenli İstatistik Teknikleri, Asil Yayın Dağııım, İstanbul.

Mcnelıs P. (2005). Neural Networks in Finance: Gaining Predictive Edge In The Market, Elsevier Academic Press.

Ocakoğlu G. (2006). Lojistik Regresyon Analizi ve Yapay Sinir Ağları Tekniklerinin Sınıflama Özelliklerinin Karșılaștırılması ve Bir Uygulama, Uludağ Üniv. Sağlık Bilimleri Enst. Biyoistatistik ABD Yüksek Lisans Tezi.

Öztemel E. (2003). Yapay Sinir Ağları, Papatya Yayıncılık.

Paket H. (2014). Borsa istanbul'da ișlem gören ișletmelerin finansal bașarısızlıklarının öngörülmesi: Yapay sinir ağları ve diskriminant analizi yöntemleri ile karșılaștırmalı bir uygulama, Süleyman Demirel Üniv. SBE. Yayınlanmamıș doktora tezi.

Schalkof, R. (1997). Artificial Neural Networks, The McGraw-Hill Companies, Inc., Newyork.

Sığırlı, D. (2006). Sınıflandırma probleminin çözümlenmesinde yapay sinir agları ile diskriminant analizinin karsılastırılması ve bir uygulama, Uludağ Üniv. Sağlık Bilimleri Enstitüsü.

Trıppı, R., Efraım T. (1996). Neural Network in Finance and Investing, Irwin Professional Publications, Chicago.

Vemurı V. (1992). Artificial Neural Networks: Concepts and Control Applications, IEEE Computer Society Press, Los Alamitos, California.

Wılkson R. L., Sharda R. (1994) Bankruptcy Prediction Using Neural Networks, Decision Support Systems, V: 11.

Yıldız B. (1999). Finansal Bașarısızlığın Öngörülmesinde Yapay Sinir Ağı Kullanımı ve Ampirik Bir Çalıșma, Dumlupınar Üniversitesi Sosyal Bilimler Enstitüsü İșletme Ana Bilim Dalı Doktora Tezi, Kütahya.

http://www.resmigazete.gov.tr/eskiler/2012/11/20121104-11.htm Erișim tarihi: 13.01 .2018 